\title{
Supplementation of Red Betel Leaf (Piper Crocatum) in Dairy Cattle Feed on Fermentation Characteristics by In Vitro
}

\author{
Caribu Hadi Prayitno ${ }^{1)^{*}}$, Suwarno ${ }^{1)}$, Doso Sarwanto ${ }^{2)}$, Dinar Hidayatun ${ }^{1)}$ and Ma'ratun Solihah ${ }^{1)}$ \\ ${ }^{1}$ Faculty of Animal Science, University of Jenderal Soedirman, Purwokerto, Indonesia \\ ${ }^{2}$ Faculty of Animal Husbandry, University of Wijayakusumah Purwokerto, Indonesia \\ *Corresponding author email: caribu_prayitno@yahoo.co.id
}

\begin{abstract}
The aim of this study was to assess the impact and efficiency of red betel leaf's extract supplementation in the diet of dairy cattle on fermentation characteristics by in vitro. The research method was experiment using completely randomized design. The evaluated treatments were R1: basal feed, R2: R1 + $15 \mathrm{ppm}$ of red betel leaf (Piper crocatum) extract, R3: R1 + 30 ppm of red betel leaf (Piper crocatum) extract, R4: R1 + 45 ppm of red betel leaf (Piper crocatum) extract, R5: R1 + 60 ppm of red betel leaf (Piper crocatum) extract. The parameters measured in this study were (1) Dry Matter Digestibility (DMD), (2) Organic Matter Digestibility (OMD), (3) total Volatille Fatty Acid (VFA). (4) methane production $\left(\mathrm{CH}_{4}\right)$ and (5) total gas production. The data were analyzed using analysis of variance followed Orthogonal Polynomial Test. The results showed that the suplementation red betel extract in the diet of dairy cow was significant $(\mathrm{P}<0.01)$ on $\mathrm{DMD}, \mathrm{OMD}$, total gas production, methane production $\left(\mathrm{CH}_{4}\right)$ and total VFA. Orthogonal Polynomial test showed the effect of treatment on Dry Matter Digestibility (DMD), total gas and $\mathrm{CH}_{4}$ gas production were in the form of cubic curve, as well as Organic Matter Digestibility (OMD) and Volatille Fatty Acid (VFA) in the form of quadrate curvewith supplementation of red betel leaf.
\end{abstract}

Key words: Red betel leaf (piper crocatum) extract, dairy cattle feed, fermentation characteristics

Abstrak. Penelitian ini bertujuan untuk mengkaji pengaruh dan efisiensi suplementasi ekstrak daun sirih merah (Piper crocatum) dalam pakan sapi perah terhadap karakteristik fermentasi secara in vitro. Penelitian dilakukan secara eksperimental menggunakan Rancangan Acak Lengkap (RAL). Perlakuan yang uji cobakan yaitu R1:Pakan Basal, R2 : R1 + 15 ppm ekstrak daun sirih merah (Piper crocatum), R3: R1 + 30 ppm ekstrak daun sirih merah (Piper crocatum), R4: R1 + 45 ppm ekstrak daun sirih merah (Piper crocatum), R5: R1 + 60 ppm ekstrak daun sirih merah (Piper crocatum).Peubah yang diukur adalah (1) kecernaan bahan kering (KBK) (2) kecernaan bahan organik (KBO)(3) VFA total (4) produksi gas metan $\left(\mathrm{CH}_{4}\right)$ dan (5) produksi gas total. Data dianalisis menggunakan analisis variansi dan dilanjutkan uji Ortogonal Polynomial. Hasil penelitian menunjukkan bahwa perlakuan berpengaruh sangat nyata $(\mathrm{P}<0,01)$ terhadap kecernaan bahan kering, kecernaan bahan organik, produksi gas total, produksi gas metan $\left(\mathrm{CH}_{4}\right)$, dan VFA total. Hasil Uji Ortogonal Polynomial menunjukkan pengaruh perlakuan kecernaan bahan kering (KBK), produksi gas total dan gas metan $\left(\mathrm{CH}_{4}\right)$ berbentuk kubik, serta perlakuan kecernaan bahan organik (KBO) dan VFA berbentuk kuadrater dengan suplementasi ekstrak daun sirih merah (Piper crocatum).

Kata kunci: Ekstrak daun sirih merah (piper crocatum), pakan sapi perah, karakteristik fermentasi

\section{Introduction}

Dairy farms represent the producers of a very useful food source, the milk. However, there are recently some inhibitors, one of which is productivity that may affect the condition of dairy cattle. The productivity factor has relationship with the feed and feeding. The major part of dairy feed is forage that has a relatively high content of crude fiber. The high content of crude fiber may result in a high production of methane, lower VFA production and DM digestibility (DMD), therefore, decrease the possibility of the nutrients to be used by the animal. Suharti et al. (2009) states the feed in the rumen is fermented by rumen microbes into energy. The fermentation in the rumen is conducted by fungi, bacteria, and protozoa that 
produce volatile fatty acids (VFA), and several kinds of gases, one of which is methane. Methane gas caused the loss of energy as much as $2-15 \%$ of the total digestible energy (Guo et al., 2008), may decrease DMD, decreased organic matter digestibility (OMD) and VFA production. The adverse condition may negatively affect the host animal. Therefore, the efforts to decrease methane production are required.

Methane gas is formed from the process of methanogenesys in the rumen by rumen microbes. The specific bacteria that produce primarily methane gas are called methanogens. There is approximately $63-80 \%$ of the methanogen that is freely active in the rumen. As much as 20-37\% (Newbold et al., 1995) of the methanogen is active symbiotically with protozoa. The methanogen- protozoa symbiosis may decrease digestibility. The bacteriophage characteristic of protozoa to fulfill its protein requirement may decrease digestibility, presumably by lowering the number of cellulolytic bacteria population that degrades crude fiber. According to Busquet et al. (2006), principally the production of $\mathrm{CH} 4$ gas in the rumen is via the reduction of $\mathrm{CO} 2$ by $\mathrm{H} 2$ that is catalyzed by some enzymes produced by the methanogens. The growth of the bacteria should be inhibited in order to optimize the dietary energy utilization into VFA production. Therefore, a strategy to suppress $\mathrm{CH} 4$ production is needed in order to increase the possibility of nutrient absorption, greater digestion, and higher VFA production, thus, the loss of energy is minimized and converted into milk production. One of the strategies that can be used is via the addition of red betel leaf (Piper crocatum) in the diet of dairy cattle. The use of plant extracts appears as one of the most natural alternatives to the antibiotic used in animal nutrition (Sirohi et al., 2009; Yang et al., 2007; Patra and Saxena, 2010; Szumaker-strabel and Cieslak, 2010;
Wanapat et al., 2007; Khalesizadeh et al., 2011; Kongmun et al.,2011; Zafarian and Manafi, 2013; Prayitno et al., 2013; Prayitno et al., 2015). Red betel (Piper crocatum) is a traditional medical herb that has a secondary metabolite namely polyphenol more specifically flavonoid that function to inhibit the growth of gram positive, as well as gram negative microorganisms. Juliantina et al. (2009), stated that red betel contains flavonoids, alcaloids, pholyphenolates, tannins, and aster oil that have the ability as antibacterial for gram positive and gram negative bacteria. Oskoueian et al. (2013), stated that the secondary metabolite contents in red betel are flavonoids and alcaloids as the compounds of antibacterial agents that may affect positively on the health of the hosts and increase feed efficiency. Alfarabi (2010) informed that the flavonoids in red betel that was extracted using ethanol $70 \%$ is myricetin that is included into a group of flavonol. The contents of flavonoid such as naringin, quercetin, flavone, myricetin, cempherol and can decrease $\mathrm{CH} 4$ production in Methanobrevibacter ruminantium bacterium (Oskoueian et al., 2013). Myricetin is a kind of flavonoid compound that is available in the red betel and is included in the group of flavonol, which has an ability to inhibit CH4 formation. Cushnie and Lamb (2005) informed that flavonoids are able to block the synthesis of plasma membrane, inhibit the synthesis of bacterial cell wall and nucleic acids. The inhibition of $\mathrm{CH} 4$ production will reduce protozoa population, in turn, it will increase DMD, OMD and VFA production in the rumen via methanogenic inhibition.

\section{Materials and Method}

\section{Materials}

The study was conducted in the Laboratory of Feedstuff Science, the Faculty of Animal Science, Jenderal Soedirman University, Purwokerto. The materials of the study were a basal feed for dairy 
cattle containing $13.38 \%$ of crude protein (CP), $23.27 \%$ of crude fiber (CF), and $62.21 \%$ of total digestible nutrients (TDN) and consisted of Napier grass and concentrate, rumen fluid of $\mathrm{FH}$-cross dairy cattle, the extract of red betel leaves, a unit of computer, in vitro DMD, OMD, $\mathrm{CH} 4$ and total gas, and VFA analyzers.

\section{Methods}

Dry matter and organic matter digestibility The determinations of DMD and OMD used Tilley and Terry (1963) method, by weighing sample as much as 2 gram of DM, and putting it in an Erlenmeyer tube, plus $16 \mathrm{ml}$ of rumen fluid and $24 \mathrm{ml}$ of McDougall's solution, sealing the tube tightly using rubber sealer, and incubated the tube in a shaker water bath for 24 hours. The temperature of of the waterbath was kept constant at $39^{\circ} \mathrm{C}$, and was flowed with $\mathrm{CO}_{2}$ gas every 4-hour intervals to make sure that the condition was always anaerobic. After 24 hours the sealer was opened, 2 drops of $\mathrm{HgCl} 2$ was added to the tube in order to kill the bacteria. The samples were then filtered to separate the residues from the supernatants. The supernatant was stored for VFA analysis. The reside of each tube was added with $40 \mathrm{ml}$ of $\mathrm{HCl}$ pepsin, reincubated for another 24 hours in a shaker waterbath at $39^{\circ} \mathrm{C}$ without shaking to optimize hydrolitic digestion in aerobic condition. The residue was filtered using Whatman no.41 filter paper. The residue then was heated in an oven, $100^{\circ} \mathrm{C}$, to determine dry matter content, and at $600^{\circ} \mathrm{C}$, to determine organic matter content.

\section{Total and methane gases}

The total gas was measured using $\mathrm{CO} 2$ trapping method (Tjandraatmadja, 1981), as followed: (1) the implements were connected to form a T-connector; (2) gas was taken using a syringe; (3) The gas in the syringe was injected into a serially connected tubes filled with a $5 \mathrm{M}$ $\mathrm{NaOH}$ solution; (4) the released gas then was collected in the second volumetric tube that functioned to collect $\mathrm{CH} 4$ gas.

\section{VFA analysis}

Prepare a vapour destilation apparatus, let it boiled. After the the destilation bulb boiled, the sample container was cleaned with aquadest. Five $\mathrm{ml}$ of supernatant was pipetted, poured into a sample tube of a vapour destilation apparatus. One $\mathrm{ml}$ of a $15 \% \mathrm{H}_{2} \mathrm{SO}_{4}$ was added into the tube, and the destilate was collected into a $250-\mathrm{ml}$ capacity erlenmeyer tube that had been filled with $5 \mathrm{ml}$ of $\mathrm{NaOH}$, until the total volume of the destilate was $100 \mathrm{ml}$. Two drops of phenolpthalein as a colour indicator was added into the destilate mixture. The mixture then was titrated with $0.5 \mathrm{~N} \mathrm{HCl}$ until the initiation of colour change. As a blank solutioan, $5 \mathrm{ml}$ of $0.5 \mathrm{~N}$ $\mathrm{NaOH}$ was titrated using $0.5 \mathrm{~N} \mathrm{HCl}$.

\section{Experimental design}

The study was conducted experimentally by in vitro. Completely randomized design was used. There were 5 treatments in which each was replicated 4 times. The treatments studied were: R1, basal feed; R2, basal feed plus 15 ppm of red betel leaf extract ; R3, basal feed plus $30 \mathrm{ppm}$ of red betel leaf extract; R4, basal feed plus 45 ppm of red betel leaf extract; R5, basal feed plus 60 ppm of red betel leaf extract. The variables measured in this study were: (1) dry matter digestibility (DMD), (2) organic matter digestibility (OMD), (3) Volatile Fatty Acid Production (VFAP), (4) methane gas production (MGP), and (5) total gas production (TGP). The data were analyzed using the analysis of variances and Orthogonal polymonial test.

\section{Results and Discussion}

The results of the study showed that the addition of red betel leaf extract gave a highly significant effect $(P<0.01)$ on DMD of dairy cattle 
feed substrate (Table 1). The data indicated that the leaf betel extract was able to affect DMD of dairy cattle feed. The values of averages of of feed DM concentrations ranged from $25.96 \%$ to $38.84 \%$. The mean values of DMD in this study were far lower compared to those of Prayitno et al. (2013), 66.06 - 72.32, who used combination herbal extract (Sapindus rarak and Garlic) in the feed of dairy cow. According to Akraim (2011), the DMD of feed that used barley straw extract was $21.7 \%$ after 12 -h incubation, and increased into $43.62 \%$ after $24-\mathrm{h}$ incubation. The further test using Orthogonal polymonial in our study showed that the addition of leaf betel extract in the feed of dairy cattle was expressed by the cubic equation, $Y=38.538-0.435-0.0003 X^{3}$ and a coefficient of regresion of $\mathrm{R} 2=67.2 \%$, meaning that the DMD of the feed was affected by leaf betel extract as much as $67.2 \%$.

Juliantina et al. (2009) stated that the ethanol extract of red betel has a potenttial as an anti bacerial agent against gram positive microorganisms (S. aureus) and gram negative ( $E$. coli). The capacity of the extract was higher as a gram positive anti bacterial agent, relative to that as antibacterial agent for gram negative.

Gram positive bacteria for example the crude fiber degrading bacteria, are sensitive to a certain polyphenol compound (Smith et al., 2003). The examples of the species of crude fiber/cellulolytic degrading bacteria include Fibrobacter succinogenes, Ruminococcus albus, Ruminococcus flavefaciens, Cillobacterium cellulosolvens. Flavonoiid as an methanogenic inhibition agent does not only decrease the population of protozoa, but also reduce other mocrobial populations. Oskoueian (2013) states that the additions of flavonoids such as flavon, myricetin, cathecin, rutin, and caempherol reduce the populations of almost the whole species of microorganisms in the rumen. In general, flavonoids oppose as well as inhibit the function of cytoplasmic membrane and the synthesis of bacterium cell wall.

Juliantina et al. (2009) stated that the ethanol extract of red betel has a potenttial as an anti bacerial agent against gram positive microorganisms (S. aureus) and gram negative ( $E$. coli). The capacity of the extract was higher as a gram positive anti bacterial agent, relative to that as antibacterial agent for gram negative. Gram positive bacteria for example the crude fiber degrading bacteria, are sensitive to a certain polyphenol compound (Smith et al., 2003).

Table 1. The means of DMD, OMD and VFAP of the rumen fermented feed in the study

\begin{tabular}{cccc}
\hline Treatment & $\begin{array}{c}\text { DMD } \\
(\%)\end{array}$ & $\begin{array}{c}\text { OMD } \\
(\%)\end{array}$ & $\begin{array}{c}\text { TVFA } \\
(\mathrm{mM})\end{array}$ \\
\hline $\mathrm{R}_{0}$ & $38.84 \pm 1.03^{\mathrm{b}}$ & $37.99 \pm 1.88^{\mathrm{b}}$ & $159.0 \pm 2.0^{\mathrm{b}}$ \\
$\mathrm{R}_{1}$ & $34.66 \pm 2.44^{\mathrm{b}}$ & $34.54 \pm 1.64^{\mathrm{ab}}$ & $164.0 \pm 5.7^{\mathrm{b}}$ \\
$\mathrm{R}_{2}$ & $38.69 \pm 6.64^{\mathrm{b}}$ & $38.41 \pm 7.23^{\mathrm{b}}$ & $162.0 \pm 11.7^{\mathrm{a}}$ \\
$\mathrm{R}_{3}$ & $34.28 \pm 1.66^{\mathrm{b}}$ & $34.75 \pm 2.07^{\mathrm{ab}}$ & $101.5 \pm 20.1^{\mathrm{a}}$ \\
$\mathrm{R}_{4}$ & $25.96 \pm 2.13^{\mathrm{b}}$ & $27.70 \pm 1.51^{\mathrm{a}}$ & $93.5 \pm 12.5^{\mathrm{a}}$ \\
\hline
\end{tabular}

R1, basal feed (13.38\% of CP, $23.27 \%$ CF, and $62.21 \%$ of TDN); R2, basal feed plus 15 ppm of red betel leaf extractkg -1 feed dry matter ; R3, basal feed plus 30 ppm of red betel leaf extractkg - 1 feed dry matter ; R4, basal feed plus 45 ppm of red betel leaf extractkg -1 feed dry matter; R5, basal feed plus 60 ppm of red betel leaf extract $\mathrm{kg}^{-1}$ feed dry matter 
The examples of the species of crude fiber/cellulolytic degrading bacteria include Fibrobacter succinogenes, Ruminococcus albus, Ruminococcus flavefaciens, Cillobacterium cellulosolvens. Flavonoiid as an methanogenic inhibition agent does not only decrease the population of protozoa, but also reduce other mocrobial populations. Oskoueian (2013) states that the additions of flavonoids such as flavon, myricetin, cathecin, rutin, and caempherol reduce the populations of almost the whole species of microorganisms in the rumen. In general, flavonoids oppose as well as inhibit the function of cytoplasmic membrane and the synthesis of bacterium cell wall.

\section{Organic matter digestibility}

The results of this study showed that the addition of leaf betel extract affected highly significantly $(P<0.01)$ on $\mathrm{OMD}$ in the feed of dairy cattle, in similar pattern as it did on DMD (Table 1). Similarly Prayitno et al. (2014) found identical responds compared to this study; the decrease in DMD was followed by the decrease in OMD and vice versa. In line with the two cases, Prayitno and Hidayat (2013) stated that the degradation of $\mathrm{OM}$ has a close relationship with the degradation of DM. Orthogonal polymonial analysis of this study revealed that the response of OMD to the addition of red betel leaf extract into the feed of dairy cattle was expressed in a quadratic curve, $Y=36.645+0.145 X-0.004 \times 2$ with a determination coefficient $(R 2)=46.54 \%$, which indicated that the addition of red betel leaf extract contributed to the OMD as much as $46.54 \%$. The peak point of the curve was $P(15$, 37.77). The values of the means of DMD in this study were close to those of Jayanegara et al., $2006,28.8-35.5 \%$, who used the agroindustry by products in their study. Sutardi (1980) stated that the value of DMD is in line with the value of $O M D$, because a part of DM is OM. As in case with DMD, OMD is also able to represent the quality of feed.

\section{Total gas production}

The results of this study showed that the addition of leaf betel extract affected highly significantly $(P<0.01)$ on TGP in the feed of dairy cattle. The addition of leaf betel extract was able to decrease TGP (Table 1). The decrease of TGP was assumed to be due tothe secondary metabolites in the extract, in forms of the flavonoids that are capable of suppressing the microorganisms that produce the gas. Wallace(2004) informed that plants produce several kinds of secondary metabolites as natural protection agents against the attacks of microorganisms. The highest reduction of TGP was achived by R2 (70.95\%), followed successively by R5 (20.39\%), R4 (8.67\%), and R3 (4.65\%). The decrease of TGP was assumed to be due to the secondary metabolites in the extract, in forms of the flavonoids that are capable of suppressing the microorganisms that produce the gas. Oskoueian (2013) found, the addition of a kind of flavonoid, mycetin, at a concentrtion of $4.5 \%(\mathrm{w} / \mathrm{w})$ was able to decrease the TGP as much as $30.6 \mathrm{ml} \mathrm{g}^{-1}$ lower compared to that of control, $36.1 \mathrm{ml} \mathrm{g-1,}$ with a percentage of decrease as much as $17.97 \%$. Orthogonal polymonial analysis of this study revealed that the response of TGP to. The addition of red betel leaf extract into the feed of dairy cattle was expressed in a cubic curve, $Y=$ $14.97-1.199 X+0.053 X 2-0.0006 X^{3}$ with a determination coefficient $(R 2)=66.21 \%$, which indicated that the addition of red betel leaf extract contributed to the TGP as much as $66.21 \%$, and the rest was the effects of other, undetected factors. 
Table 2. The means of Total Gas, and Methane Gas of the rumen fermented feed in the study

\begin{tabular}{ccc}
\hline Treatment & Total Gas $(\mathrm{ml} / \mathrm{mg})$ & Methane $\mathrm{Gas}(\mathrm{ml} / \mathrm{mg})$ \\
\hline$R_{0}$ & $15.575 \pm 0.50^{\mathrm{c}}$ & $6.48 \pm 0.75^{\mathrm{b}}$ \\
$\mathrm{R}_{1}$ & $4.525 \pm 0.42^{\mathrm{a}}$ & $2.13 \pm 0.15^{\mathrm{a}}$ \\
$\mathrm{R}_{2}$ & $14.85 \pm 0.78^{\mathrm{c}}$ & $6.33 \pm 0.15^{\mathrm{b}}$ \\
$\mathrm{R}_{3}$ & $14.225 \pm 0.85^{\mathrm{c}}$ & $6.30 \pm 0.30^{\mathrm{b}}$ \\
$\mathrm{R}_{4}$ & $12.4 \pm 1.65^{\mathrm{b}}$ & $5.93 \pm 0.31^{\mathrm{b}}$ \\
\hline
\end{tabular}

R1, basal feed (13.38\% of CP, $23.27 \% \mathrm{CF}$, and $62.21 \%$ of TDN); R2, basal feed plus $15 \mathrm{ppm}$ of red betel leaf extractkg -1 feed dry matter; ; R3, basal feed plus 30 ppm of red betel leaf extractkg -1 feed dry matter ; R4, basal feed plus 45 ppm of red betel leaf extractkg -1 feed dry matter, ; R5, basal feed plus $60 \mathrm{ppm}$ of red betel leaf extract $\mathrm{kg}^{-1}$ feed dry matter.

\section{Methane gas production}

The results of this study showed that the addition of leaf betel extract affected highly significantly $(P<0.01)$ on methane in the feed of dairy cattle. The addition of leaf betel extract was able to decrease TGP (Table 2). The decrease of $\mathrm{CH} 4$ production (MGP) was assumed to be due to the secondary metabolites in the red betel leaf extract in the forms of flavonoids (myricetine) that are capable of suppressing the microorganisms that produce the gas via methanogenesis. Patra and Saxena (2010) informed that the flavonoids give the direct effects in the processes of methanogenesis and protozoa reduction. The fair decrease of $\mathrm{CH} 4$ production, $67.18 \%$, was from the R2 treatment, the dairy cattle feed containing $15 \mathrm{ppm}$ of Piper crocatum leaf extract. The successive decrease of $\mathrm{CH} 4$ production were those of $\mathrm{R} 5, \mathrm{R} 4$, and $\mathrm{R} 3$. In percentages, the decrease of $\mathrm{CH} 4$ productions ranged from $2.32-67.18 \%$. These results differed from those of Bodas et al. (2008) the extracts of plants that rich in flavonoids may reduce $\mathrm{CH} 4$ as much as $4.7-14 \%$ after 24 hours of incubation. Kim et al. (2015) found out that the extract of the flower of Kamelia plant was able to decrease $\mathrm{CH}_{4}$, $22.61 \mathrm{ml} \mathrm{g}$-1 lower relative to control, $29.90 \mathrm{ml} \mathrm{g-}$ 1 , equaled with 24.38 percentage units. The data showed that the extract of the plant was able to decrease $\mathrm{CH}_{4}$ production. The addition of plant extract into the rumen is able to inhibit methanogenesis by reducing $\mathrm{CH}_{4}$ concentration and acetate, and increasing the concentrations of propionate and butyrate (Busquet et al., 2006). Orthogonal polymonial analysis of this study revealed that the response of $\mathrm{CH} 4$ production to the addition of red betel leaf extract into the feed of dairy cattle was expressed in a cubic curve, $Y=$ $6.237-0.476 X+0.021 X^{2}-0.0002 X^{3}$ with a determination coefficient $(R 2)=66.79 \%$, which indicated that the addition of red betel leaf extract contributed to the $\mathrm{CH}_{4}$ production as much as $66.79 \%$, and the rest was the effects of other, undetected factors. The decrease in $\mathrm{CH}_{4}$ concentration was assumed to be due to the inhibition of $\mathrm{CH}_{4}$-producing microorganism activity. The idea of mechanism of $\mathrm{CH}_{4}$ inhibition in the ruminants was revealed by Tavendale et al. (2005) via two directions; (1) indirect mechanism through the inhibition of crude fiber digestion, therefore, $\mathrm{H}_{2}$ production is reduced, (2) direct mechanism, via the inhibition of the growth and activity of the methanogenic archaea in the rumen. The inhibition of $\mathrm{CH}_{4}$ production due to the addition of red betel extract is included into the direct mechanism as it was described by Oskoueian et al.(2013). The content of red betel extract for example flavonoids/myricetin is able to decrease $\mathrm{CH}_{4}$ production by the bacterium of Methanobrevibacter ruminantium. The mechanism of myricetin in the inhibition of 
methanogenic bacteria was explained by Cushnie and Lamb (2005), the flavonoids inhibit plasm membrane and cell wall synthesis, and the synthesis of nucleic acid. Therefore, the decrease in methanogenic bacterium population, resulted in the decrease of $\mathrm{CH} 4$ concentration. Animal species, breed, rumen $\mathrm{pH}$, ratio of $\mathrm{C} 2$ to $\mathrm{C} 3$, methanogenic microotganism population, ration and concentrate compositions, may affect $\mathrm{CH}_{4}$ emision (Busquet et al., 2006). The results of measurements to reveal the relationship between $\mathrm{pH}$ and TGP during 6, 24, and 48 hours showed that the lower the $\mathrm{pH}$, the higher the $\mathrm{CH}_{4}$ production. The results were comparable to those of Kim et al. (2015) a study using pomegrenade fruits showed that the 6,24 , and 48-hour fermentation periods resulted in the successive pHs of 7.31, 6.71, and 6.46, and yielded the increasing $\mathrm{CH}_{4}$ concentration means of $1.63,8.31$, and $22.31 \mathrm{ml} \mathrm{g-1}$, respectively. It meant that the lower $\mathrm{pH}$ resulted in the higher $\mathrm{CH} 4$ concentration. Tillman et al. (1998) stated that the low $\mathrm{pH}$ of rumen may result in the increase of rumen microbial activity, which in turn, may increase digestibility and $\mathrm{CH}_{4}$ production. Prayitno and Hidayat (2013) informed that the high production of gasses is in line with high digestibility of feed and low rumen $\mathrm{pH}$.

\section{Total Volatile Fatty Acid production}

The results of this study showed that the addition of leaf betel extract affected highly significantly $(P<0.01)$ on TVFA in the feed of dairy cattle. The means of VFAP ranged from 93.5 to $164 \mathrm{mM}$ (Table 1). The results of Prayitno et al. (2014) showed that the means of TVFA were approximately equal, namely $86.40-187.40 \mathrm{mM}$ compared to the addition of red betel leaf extract in this study. The decrease of TVFAP was assumed to be due to the secondary metabolites in the red betel leaf extract in the forms of flavonoids (myricetine) that are capable of suppressing the microorganisms that produce the TVFA. The antibacterial compounds in the betel was assumed to be the cause of the low TVFA concentration. The compounds may inhibit the activity of the rumen bacteria. Sewet (1997) stated that was in line with this study; the concentrations of VFA in the rumen fluid is able to express one of the indicators of ruminal fermentation of feeds that has very close relationship with rumen microbial activity. Orthogonal polymonial analysis of this study revealed that the response of $\mathrm{CH} 4$ production to the addition of red betel leaf extract into the feed of dairy cattle was expressed in a quadratic curve, $Y=162.629-0.319 X+0.027 \times 2$ with a determination coefficient $(R 2)=76.87 \%$, which indicated that the addition of red betel leaf extract contributed to the $\mathrm{CH}_{4}$ production as much as $76.87 \%$, and the rest was the effects of other, undetected factors.

\section{Conclusions}

The addition of red betel leaf (Piper crocatum) extract in dairy cattle feed up to the level of 60 ppm tended to decrease digestibility (dry matter and organic matter), Volatile Fatty Acids production, total gas production and methane gas production by in vitro.

\section{References}

Akraim F. 2011. The Effect of Rosmarinus Officinalis or Saliva Officinalis Dried Leaves on the In Vitro Dry Matter Digestibility of Barley Straw. Original Scientific Paper. Zagreb 6:215-219.

Alfarabi M. 2010. In Vitro Study of Anti-diabethogenics of Red Betel Leaf (Piper crocatum)]. Tesis. Program Pascasarjana. Institut Pertanian Bogor. (In Indonesia).

Bodas R, S Lopez, M Fernandez, R Garcia-Gonzalez, A B Rodriguez, R J Wallace and J S Gonzalez. 2008. In vitro screening of the potential of numerous plant 
species as antimethanogenic feed additives for ruminants. Anim. Feed Sci. Technol. 145:245-258.

Busquet M, S Calsamiglia, A Ferret, C Kamel and W Cardozo. 2006. Plant extracts affect in vitro rumen microbial fermentation. J. Dairy Sci. 89:761-771.

Cushnie TPT and AJ Lamb. 2005. Antimicrobial activity of flavonoids. International Journal of Antimicrobial Agents 26(5):343-356.

Guo YQ, J-X Liu, Y Lu, WY Zhu, SE Denman and CS McSweeney. 2008. Effect of tea saponin on methanogenesis, microbial community structure and expression of mcrA gene, in cultures of rumen micro-organisms. Letter Applied of Microbiology. 47: 421-426.

Jayanegara A, AS Tjakradidjaja and T Sutardi. 2006. Fermentabilty and in vitro digestibility of agroindustrial waste supplemented with inorganic and organic chromium]. Med. Pet. 29:54-62. (In Indonesia).

Juliantina F, DA Citra, B Nirwani, T Nurmasitoh and ET Bowo. 2009. [Benefit of Red Betel (Piper Crocatum) as Anti-bacteria Agent against Gram Positive and Negative Bacteria]. Jurnal Kedokteran dan Kesehatan Indonesia 1(1):1-5. (In Indonesia).

Kim ET, LL Guan, SJ Lee, SM Lee, SS Lee, D Lee, SK Lee and SS Lee. 2015. Effects Flavonoid-rich Plant Extracts on In vitro Ruminal Methanogenesis, Microbial Populations and Fermentation Characteristics. Asian-Australas. Anim Sci. 28:530537.

Kongmun P, M Wanapat, P Pakdee, C Navanukraw and Z Yu. 2011. Manipulation of rumen fermentation and ecology of swamp buffalo by coconut oil and garlic powder supplementation. Livestock Sci. 135: 84-92.

Khalesizadeh A, A Vakili, MD Mesgaran and R Valizadeh. 2011. The Effect of garlic Oil (Allium sativa), Turmeric Powder (Curcuma longa Linn) and Monensin on Total Apparent Digestibility of Nutrients in Balloochi Lambs. World Academy of Science, Eng. and Tech. 59:2065.

Newbold R, J Wallace and FM Mcintosh. 1995. Mode of action of the yeast Saccharomyces cerevisiae a feed addictive for ruminant. Br J Nutr. 76:249-261.

Oskoueian E, N Abdullah and A Oskoueian. 2013. Effects of Flavonoids on Rumen Fermentation
Activity, Methane Production, and Microbial Population. BioMed Research Inter. 1:1-8.

Patra AK and J Saxena. 2010. A new perspective on the use of plant secondary metabolites to inhibit methanogenesis in the rumen. Phytochemistry 71:1198-1222.

Prayitno $\mathrm{CH}$ and $\mathrm{N}$ Hidayat. 2013. The Efficacy of methanol extract of Garlic (Allium sativum) to improve rumen fermentation products. J. Anim. Production. 15(1):69-75.

Prayitno CH, Y Subagyo and Suwarno. 2013. Effect of Sapindus rarak Extract alone or Its combination with garlic extract on in vitro ruminal fermentation. Med. Pet. 36 (1):52-57.

Prayitno CH, TR Sutardi and Suwarno. 2014. Supplementation effect of Herbal and organic minerals in beef cattle feed on consumption, digestibility, efficiency and daily gain. J. Anim. Production. 16(2):88-94.

Prayitno $\mathrm{CH}$, Suwarno and A Susanto. 2015. In vitro assessment of digestibility and rumen fermentation of ammoniated rice straw based beef diet, supplemented with extract of garlic and Sapindus rarak. Livestock research for Rural Dev. 27(5):1-8.

Sewet U. 1997. Population dynamics and activity of rumen microbial fermentation of goat fed calliandra (Calliandra calothyrsus)]. Tesis. Program Pasca Sarjana. Institut Pertanian Bogor. Bogor. (In Indonesia).

Sirohi SH, N Pandey, N Goel, B Singh, M Mohini, P Pandey and PP Chaudhry. 2009. Microbial activity and ruminal methanogenesis as affected by plant secondary metabolites in different plant extracts. International J. Civil and Enviromental Enginering. 1:52-58.

Smith AH, E Zoetendal and RI Mackie. 2005. Bacterial mechanisms to overcome inhibitory effects of dietary tannins. J. Microbial Ecology. 50 (2):197205.

Suharti S, A Astuti and E Wina. 2009. Nutrient digestibility and production performance of Ongole Cattle Cross (PO) Fed with Lerak Flour (Sapindus rarak) in the ration]. JITV 3:2000-2007. (In Indonesia). 
Szumacher-Strabel M and A Cieslak. 2010. Potential of phytofactors to mitigate rumen ammonia and methane production. J. Anim.Feed Sci.19:319-337.

Tavendale MH, LP Meagher, D Pacheco, N Walker, GT Attwood and S Sivakumaran. 2005. Methane production from in vitro rumen incubation with Lotus pedunculatus and Medicago sativa, and effect of extractable condensed tannin fractions on methanogenesis. Anim. Feed Sci. Technol. 123/124: 403-419.

Tjandraatmadja M. 1981. Anaerobic Digestion of Fibrous Materials. A Thesis of Master of Agricultural Science. University of Melbourne, Australia.

Tillman AD, H Hartadi, S Reksohadiprojo, S Prawirokusumo and S Lebdosoekojo. 1998. Fundamental of Nutrition. Edisi ke-5. Gadjah Mada University Press, Yogyakarta. (In Indonesia)
Yang WZ, C Benchaar, BN Ametaj, AV Chaves, ML He and T A McAllister. 2007. Effect of Garlic and Juniper Berry Essential Oils on Ruminal Fermentation and on the Site and Extent of Digestion in Lactating Cows. J. Dairy Sci. 90 : 56715681

Wallace RJ. 2004. Antimicrobial Properties of Plant Secondary Metabolites. Proceedings of The Nutrition Society 63:621-629.

Wanapat M, P Khejornsart, P Pakdee and S Wanapat. 2008. Effect of Supplementation of Garlic Powder on Rumen Ecology and Digestibility of Nutrients In Ruminants. J. Sci. Food Agric. 88:2231-2237.

Zafarian R and M Manafi. 2013. Effect of garlic powder on methane production, rumen fermentation and milk production of Buffaloes. Annual Rev Res in Biology. 3(4):1013-1019. 